\title{
The Comparison of the American Dream and the Chinese Dream
}

\author{
Xuan Pan \\ Sichuan University, Chengdu, China.
}

How to cite this paper: Xuan Pan. (2020) The Comparison of the American Dream and the Chinese Dream. Journal of Humanities, Arts and Social Science, 4(2), 159-164.

DOI: 10.26855/jhass.2020.07.010

Received: November 8, 2020

Accepted: November 30, 2020

Published: December 9, 2020

*Corresponding author: Xuan Pan, Sichuan University, Chengdu, China. Email: NCA2020@foxmail.com

\begin{abstract}
This essay focuses on the widely used phrases "the American Dream" and "the Chinese Dream". In this essay, the author traces the origins and developments of the American Dream and the Chinese Dream and finds that they were both produced by specific social environment and changes. Then by comparing these two terms, the author finds that there are both relevance and differences between them. In Chinese history, the introduction of American Dream once made effects on Chinese views of America, and the way Chinese people understand the American Dream reflects how Chinese view themselves from time to time. The idea that using Chinese Dream to construct the national image of China came from the widespread of the American Dream, as a response to the prevalence of the China Threat Theory. The difference is mainly in their different ways of getting wide-spread that the American Dream developed from bottom to top while the Chinese Dream develop conversely; and in their definition emphases that the American Dream refers more to individual success while the Chinese Dream give priority to the revitalization of Chinese nation. Admittedly, there are natural difference between the American Dream and Chinese Dreams they emerged from very different cultural, but regardless of differences, these Dream shares an essential vision that is to create a better world in which people can live a high-quality life.
\end{abstract}

\section{Keywords}

The American Dream, the Chinese Dream, Sino-American relations, Cross-cultural communication

\section{Introduction}

The American Dream is a term referring to a widely held belief in America. One of the earliest definitions of the American Dream was "that dream of a land in which life should be better and richer and fuller for everyone, with opportunity for each according to ability or achievement" by Adams in 1931. After that, the phrase rapidly entered common parlance (Cullen, 2003, p. 4). Though people use different words to describe their understanding of the American Dream, the core of it remained that all men, regardless of their social class or the circumstance of birth, have opportunities to achieve a better life through hard work in America.

This belief is produced by specific political, cultural and economic environment, and varies its emphasis along with social changes. As a social belief with a long history, it not only roots in American culture but also makes a worldwide influence with the huge expansion of American popular culture during the twentieth century.

When this foreign national ethos was introduced to the Chinese, it was interpreted and adopted to accommodate Chinese needs. Comparing the earlier description of the American Dream with the present one in Chinese popular 
culture, Chinese attitude towards this theme has changed. And the way Chinese people understand the American Dream reflects how Chinese view themselves from time to time.

In 2012, Xi Jinping, the Chinese President, first introduced an expression of Chinese national and personal ethos and ideals, which is called the Chinese Dream. The American Dream and the Chinese Dream, though share similar names, have very differentiated focuses based on the disparate social and cultural realities the two nations have experienced in history.

Previous research comparing the American Dream and the Chinese Dream has found the differences in the definitions of two terms. Shi (2013) summed up seven differences between the American Dream and the Chinese Dream; Zhu (2013) compared the American Dream and the Chinese Dream in their different definitional connotations, cultural causes, fundamental values, ways of realization, goal, prospective and effects. In contrast, few literatures explored the relations and common values between them. There are certain differences between the American Dream and the Chinese Dream, but in the context of today's cultural and political conflicts between these two countries, for promoting cultural exchanges and mutual understanding, it is necessary to expand further discussion on the relations between them.

This study will provide new insights into the comparative study between the US-China relationships from an interdisciplinary perspective of history, culture and politics. In analyzing the changing views of the American Dream in both America and China, I will first explore social changes which had impacts on people's understandings of the American Dream in both countries. Then, I will compare and contrast the connections and differences between the American Dream and the Chinese Dream in both political and cultural realms.

\section{Changing Views of the American Dream}

Researchers trace the American Dream back to the period of European colonization in America. Because the wealth inequality, stiff hierarchy and religious discrimination in Old Europe limited the development of individuals, the early colonists, mainly impoverished laborers, landless peasants, and British Puritans, came to the New Land and dreamed to find their opportunities. The Pilgrims and Puritans are regarded as the representative of the American Dream at that time. The Pilgrims and Puritans came to the empty land because they believed that they were chosen people who followed a "call" from God coming to the "promised land" (Cullen, 2003, p. 16). In the process of building the early colonies, the Puritans' ethic of hard work made contributions to the forming of the American ethos.

By the time of the American revolution, the Founding Fathers became the compelling spokesmen of the American Dream, they gave a promise that everyone can chase the American Dream in The Declaration of Independence (1776), which proclaims: "all men are created equal, that they are endowed by their Creator with certain unalienable Rights, that among these are Life, Liberty, and the pursuit of Happiness”. With similar words amid the Declaration and US Constitution, later American generations were entitled to dream their own American Dream.

After the Civil War, because of the economic development and social changes, the phrase began to emphasize more on commercial success than before. From that time on, a number of literary works describing the limits or infeasibility of the American Dream emerged, like the Gilded Age, Sister Carrie, The Great Gatsby, and so on.

In 1963, in his well-known speech I have a dream, Martin Luther King expressed the dream of freedom by delivering that he had "a dream deeply rooted in the American dream". Though share the same name, Puritans and African Americans in the civil war sought different kinds of freedom, the former required freedom of religion while the African slavers required the literal freedom (Cullen, 2003, p. 59). The consistent prevalence of the phrase the American Dream reflects in its elasticity that everyone can use it to name his or her dream.

Nowadays, American politicians also show a preference to the American Dream. According to Wolak and Peterson (2020), the American Dream appears in the Congressional Record over 500 times during the $114^{\text {th }}$ Congress and is named in the title of four bills introduced during the session. Even though it has been used as a political tool to rouse the resonance from the public, Americans hold conflicting attitudes towards the American Dream. On the one hand, it still symbolizes the promise to get success, on the other hand, their belief in the American Dream is responsive to real-world conditions including the level of income equality and social mobility and short-term economic performance (Wolak \& Peterson, 2020).

Apart from the personal belief, the American Dream also contains a global vision that is to promote the American Models featured by its political system, free market, American culture and so on around the world. A belief in American culture is that Americans can realize the dream of founding a new country was because they are "chosen people", and they have the mission to lead other nations. This resulted in the American Exceptionalism and the fol- 
lowing American Paternalism. The conviction that the America has the duty to help China achieve its industrialization and modernization, therefore affected its policies on China (Shambaugh, 2013).

\section{The American Dream Coming to China}

The earliest Chinese practice for chasing the American Dream was the labor going to earn money in America in the late Qing Dynasty. Considering the increasingly severe domestic social crisis in politics and the economy, a large group of laborers chose to make their lives abroad. After the Second Opium War, the Qing government signed treaties with western countries, in which the Chinese laborers' going abroad was legalized in China. For instance, SEC. 5 in the Convention of Peking (1860) lied down for Chinese laborers' gonging and working abroad. The Burlingame Treaty (1868) laid down that America and China "cordially recognize the inherent and inalienable right of man to change his home and allegiance, and also the mutual advantage of the free migration and emigration of their citizens and subjects respectively from the one country to the other”. These treaties heated the wave of Chinese working abroad.

On the one hand, the America domestic society was witnessing severe social crisis in economy and politics, coupled with frequently-happened natural disasters. On the other hand, with the growing demand for Chinese cheap labor, western merchants found it a profitable business to trade Chinese laborers abroad. The domestic and international factors both contributed to a wave of immigration (He, 2017).

As the same as other immigrants from all over the world came to America, the promise of the American Dream attracted Chinese to chase their dream there. These Chinese workers took actual action to pursue their dream of making a better life. However, the U.S. Congress introduced the Chinese Exclusion Act on May 6, 1882, which stipulated that the coming of Chinese laborers to the United States should be suspended, and any Chinese laborer would not be allowed to come America during suspension (1882). The Chinese Exclusion Act was continued by the Geary Act in 1992 which did not schedule an end time and then was eventually abolished by the Magnuson Act in 1943.

A group of Chinese government-funded students went to the U.S. for study, especially after the remission of the Boxer Indemnity. Contrasting to Chinese laborers going to American for solving the problem living, these students went there for a dream of building a stronger country after finishing their study and coming back home. Between 1909-1911, the Qing government sent 180 students to America in total, 62.7\% of them studied engineering, agriculture, medical science and 33.6\% studied literature, history, philosophy, politics, and law (Hu, 2013). Out of these students, many became famous social activists, for instance, Hu Shi, Wang Shijie and Luo Jialun. These students also became main resources of universities and colleges faulty and some of them became famous educators (Hu, 2013), like Mei Yiqi, who then became the school master of Tsinghua University in 1931. Hu Shi, who then became a leader of the New Culture Movement, was one of the second batch students going to America through the remission of the Boxer Indemnity. He once said: "My interest in American electoral system, my research on American political system and my experience of the two elections result to my consideration of Chinese politics and government". As a famous slogan "Democracy and Science" of the New Culture Movement said, in the views of advocates for this movement, America was the example of democracy for China.

Between 1946 and 1949, because of the war, only 193 Chinese students going to America for study. Then, as America and China were allies in the Second World War, the benign relationships between two countries facilitated the wave of going to study in America. The number of students going to America enjoyed an increase after the end of the war and hit the peak in 1949 (Hu, 2013).

After the rapprochement of diplomatic ties between the U.S. and the People's Republic of China (PRC) in 1972, another wave of immigration and overseas studying appeared. As the Reform and Opening Policy was introduced in 1978, China began to enter the global economic and social environment where abundant opportunities can be found. With the increasing demand of Chinese for knowing what the world was like, an amount of cultural work showing American society gets popularity. Among these, the Chinese students and immigrants in America provided many wide-spread works describing how they chase their American Dreams. For instance, a novel serialized in Beijing Evening, A Native of Beijing in New York presented what happened to a Chinese cellist who came to America. It rose enthusiastic response from readers, then was filmed and became the first TV series shot overseas. Works like this made more Chinese fascinated by American lifestyle, ideology and culture in turn (Zhang, et al., 2013). Besides the demand for the knowledge of foreign countries, the popularity of the American Dream is also a manifestation of American cultural expansion in China. The American media and the government used "the Chinese American Dream" (Chinese or American Chinese who pursuing and achieving their dreams in America) as an example to optimize its national image (Zhai, 2017). 


\section{The comparison of the two Dreams}

According to Wang (2013), the phrase "Chinese Dream” can date back to a classical Chinese poetry written by Zhen Sixiao, a poet and painter in the Southern Song Dynasty, in which the poet used "ZhongGuoMeng” (ZhongGuo [China] here donated to the Central Plain used to be Song's state) to express his desire for revendication. A drama called ZhongGuoMeng [the Chinese Dream] was presented in Shanghai People's Art Theater in July 1987. In this play, the "Chinese Dream" mainly expressed the fever of Chinese Culture and the hope for China's development and prosperity. After that, the usage of this phrase showed a rise. However, although the phrase was used in many articles or books, the meaning of this phrase did not show accordance (Wang, 2013).

The heater discussion about the Chinese Dream among Chinese intellectuals and press began from 2006 upon the prevalence of China Threat Theory in western countries. In response to the American Dream that emerged from the developmental history of America, the term "Chinese Dream" was proposed to help Chinese communicate with the West better (Wang, 2013). Then many meetings or seminars about the Chinese Dream came forth continuously. The early advocation that using the Chinese Dream to contrast China's national image was partly inspired by the widespread and prevalence of the American Dream around the world. It was used to show the international society that China, as an emerging economy, is never a threat for anyone, on the contrary, it has prepared to make its contribution to the development of the welfare of all mankind.

After Chinese President Xi Jinping introduced this term to describe a set of personal and national ethos in China, it has become widespread in official announcements and a social heated expression into Chinese daily life. Xi defined the Chinese Dream is "to achieve the great revitalization of the Chinese nation" in a visit to the National Museum of China on November 29, 2012 (Cheng, 2012). Xi further elaborated that "to achieve the great revitalization of the Chinese nation is to achieve national prosperity and rejuvenation, and people's well-being” on March 18, 2013 (Chang, 2013). According to Zhang and Hong (2016), the Chinese Dream became an internet buzzword upon Xi's speech on November 29, 2012 and it was from this time point that Chinese netizens began to pay more attention to the Chinese Dream than to the American Dream. In June 2013, the quantity reached a higher peak upon the Xi's visit to the US and meet with US President Obama.

Base on the analysis above, one of the differences between the Chinese Dream and the American Dream is that they emerged in different ways. The American Dream is a spontaneous collective concept from American mass culture and then became a belief so widely accepted that even presidential candidates used it to help their election campaign. Its development pattern is from the bottom up. By contrast, the Chinese term was adopted by Chinese intellectuals for cross-cultural communicating aims at the beginning and then entered the public discourse, so it developed from top to bottom.

Therefore, compared with the American Dream accepted as a mass discourse, the Chinese Dream is regarded as one of the tools Chinese government applying to improve its national soft power (Ho, 2018; Servaes, 2014). And like the global prevalence of the American Dream companying with American cultural expansion into other countries, there is also a concern that "as China pursues its vision for its place in the world, some worry it is becoming expansionist and aggressive” (Stout, 2013) than before. Chinese state's response to this view is definite. Xi clearly stated that the Chinese Dream is never a "dream of hegemony" when meeting with foreign representatives at the 2019 New Economy Forum. He said China is not to replace any country but to retrieve deserved dignity and status of Chinese nation (Zhou, 2019).

There are also definitional differences between two terms. These come from respective cultural traditions and history of two countries. China, though experienced various dynasties, is always a united country under the ruling of relatively sole authority and therefore collectivism become a mainstream value while individualism forged America's frontier society. The difference reflected in the definition of two concepts was that: the Chinese Dream emphasizes the prosperity of country, the harmony of society and happiness of the citizens while the American Dream stresses personal wealth, freedom and happiness; the Chinese Dream refers to the dream of the revitalization of the nation while the American Dream values the dream of individual success; the former stresses that the Chinese Dream must be achieved by Chinese people while the America Dream once used as propaganda to attract immigrants to the U.S.

Hence, as the American Dream has been proved by famous success stories of some rags-to-riches stories again and again, now when people heard this world, Bill Gates, Barack Obama, and countless successful social celebrities may appear in their minds. In contrast, when it comes to the Chinese Dream, people may remind of China as a country rather than specific individuals. 


\section{Conclusion}

The development of the American Dream is parallel with the history of America. It can be traced back to the religious mission that the Puritans wanted to build up a new world beyond Europe. Its consistent prevalence is from its elasticity that it can be applied to everyone dreaming of a dream and being willing to achieve the dream through hard-work. The meaning of the American Dream varied with time as the response to the social changes. In turn, the American Dream has made the influence on the national political and diplomatic policies.

The earliest Chinese practice of chasing the American dream was the laborers' going to America for working in the late Qing Dynasty. After the rapprochement of diplomatic ties between the U.S. and the PRC, especially after the Reform and Opening Policy, the publicity of the American Dream enjoyed a reception among Chinese through the cultural works produced by the early immigrants, students and their descendants. For one, the Chinese showed a growing demand for knowing the world and other countries. For another, The American Dream used to be a tool of American national image construction and contributes to its cultural expansion during the $20^{\text {th }}$ century.

The idea that using Chinese Dream to construct the national image of China partly came from the widespread of the American Dream. At that time, the China Threat Theory owned its resonance in western countries. Then Chinese intellectuals proposed to construct a term "Chinese Dream" to define the national ethos of Chinese. On the other hand, as the Chinese got more knowledge of foreign countries, they also began to rethink their own culture, and tried to reposition Chinese culture in international society. Since Chinese president Xi Jinping promoted the Chinese Dream in November 2012, this term showed up increasingly frequently in Chinese popular culture. As the American Dream contains a universal value that everyone has the right to pursue a better life, the Chinese Dream also expresses a global vision that is to build a harmonious world.

Comparing the Chinese Dream and the American Dream, the difference is mainly in their different ways of getting wide-spread that the American Dream developed from bottom to top while the Chinese Dream develop conversely; and in their definition emphases that the American Dream refers more to individual success while the Chinese Dream give priority to the revitalization of Chinese nation. Admittedly, there are natural differences between the American Dream and Chinese Dream as they emerged from very different cultural, but regardless of differences, these Dream shares an essential vision that is to create a better world in which people can live a high-quality life. This essay helps to improve the mutual understanding of two cultures, which will facilitate to solve the consistent conflicts happened between America and China in the long run.

Because of limited resources and coverage, this study narrows comparative research of two culture to the specific two terms "American Dream" and "Chinese Dream”. Besides, as the most of literatures I refer to were by Chinese researchers, the essay fails to present the international responses and evaluation to the newly created term "Chinese Dream" in a more comprehensive way. In addition, is Chinese people's belief of Chinese Dream is correlated to economy, social stability and relative factors can be further researched by quantitative study.

\section{Acknowledgement}

I would like to extend my sincere gratitude to my supervisor Juno Sun. I attended Juno's course called China according to American Popular Culture: US-China relations from the Reconstruction Era to 1949, which provides me a systemic understanding of history of Sino-US relations. She gave me many instructive advices and useful suggestions on my essay. I am deeply grateful for her teaching and help.

I am also deeply indebted to all other tutors and teachers who have encouraged me, gave me writing advices with great patience: Una, Ms. Lu.

Finally, my thanks would go to my beloved family for their loving considerations during the period of my writing.

\section{References}

Adams, J. (1931). The Epic of America. New York: Little, Brown and Company.

Chang, X. (2013, March 17). Xi Jinping Delivered an Important Speech at the Closing Meeting on the first session of the $12^{\text {th }}$ National People’s Congress. Retrieved August 18, 2020 from http://jhsjk.people.cn/article/20816352.

Cheng, H. (2012, Novermber 30). Xi Jinping: Build on the Past: Forge Ahead Toward the Great Goal of Revitalizing the Chinese Nation. Retrieved August 18, 2020 from http://jhsjk.people.cn/article/19746089.

Cullen, J. (2004). The American Dream: A Short History of an Idea that Shaped a Nation. (pp. 4, 16, 59). Oxford (England): Oxford University Press. 
He, J. (2017). Research on the Chinese Laborers Novels. (Master). Shanghai Normal University.

Ho, W. C. (2018). Power, Public Diplomacy, and Cultural Diplomacy in China's Education: From Soft Power to the Chinese Dream. In: Culture, Music Education, and the Chinese Dream in Mainland China. Cultural Studies and Transdisciplinarity in Education, vol 7. Springer, Singapore.

Hu, S. (2013). Social Changes and the Great Upsurge of Studying in USA in Modern China. Journal of Hainan Normal University, 2013(09), 58-63.

Hu Shi. (1992). Oral Biography of Hu Shi ( $2^{\text {nd }}$ ed.) (D, Tang, Trans.). (pp. 40). Beijing: Sino-Culture Press.

King, M. (1963). I Have A Dream. Speech, Lincoln Memorial, Washington.

Serveas, J. (2014). Soft power and the Chinese dream. Retrieved August 18, 2020 from https://waccglobal.org/soft -power-and-the-chinese-dream-\%E4\%B8\%AD\%E5\%9B\%BD\%E6\%A2\%A6/.

Shambaugh, D. (2013). Tangled Titans: The United States and China. Maryland: Rowman \& Littelfield Publishers.

Shi, Y. (2013). Seven Differences Between the American Dream and the Chinese Dream. People's Tribune, 2013(15), 46-47.

Stout, K. (2013). Is Xi Jinping’s “Chinese dream” a fantasy? Retrieved August 18, 2020 from https://edition.cnn.com/2013/05/26/world/asia/chinese-dream-xi-jinping/index.html.

The Declaration of Independence. (1776, July 4). Washington: U.S. National Archives \& Records Administration.

Transcript of Chinese Exclusion Act. (1882). Retrieved August 15, 2020 from www.ourdocuments.gov.

Wang, J. (2013). The Origin of the Words “China Dream”. Contemporary China History Studies, 2013(6), 110-128.

Wolak, J. and Peterson, D. A. M. (2020). The Dynamic American Dream. American Journal of Political Science.

Zhai, T. (2017). “The Chinese American Dream” Narrative and the Construction of American National Image: also about the Propaganda Policy of US Government Towards the Overseas Chinese in the 1950s-60s. The Chinese Journal of American Studies, 2017, 31(02): 119-141+7.

Zhang, X. and Hong, Y. (2017). A correlative Study of the Internet Trends between the Chinese Dream and the American Dream: Empirical Test Based on the Baidu Index and the Goole Index. Journal of Xiamen University (Arts \& Social Sciences), 2017(5).

Zhang, et al. (2013). The Image of America in the Chinese contemporary mass culture China. Theory and Criticism of Literature and Art, 2013(5), 43-52.

Zhu, J. (2013). What's the Difference between the “Chinese Dream” and the "American Dream”? Journal of Socialist Theory Guide, 2013(03), 14-15+33

Zhou, C. (2019). Xi Jinping: The Chinese Dream is not a dream of hegemony. Retrieved October 18, 2020 from http://www.xinhuanet.com/politics/leaders/2019-11/22/c_1125264137.htm. 